\title{
Criminal Aspects For Legal Processing On Persons Abuse of Illegible Drugs
}

\author{
Yanto Mulyanto $\mathrm{P}^{*}$ ) and Achmad Sulchan**) \\ ${ }^{*}$ Indonesian National Police, E-mail: mulyanto08.my@gmail.com \\ ${ }^{* *}$ Universitas Islam Sultan Agung (UNISSULA) Semarang
}

\begin{abstract}
The purpose of this study is to find out, examine and analyze the implications of the criminal aspect in the implementation of the Health Law on perpetrators of drug abuse. This research uses normative juridical method. Based on the research, it can be concluded that in the application of the criminal act of distributing and abusing pharmaceutical preparations without a distribution permit as regulated in Article 197 of Act No. 36 of 2009 concerning Health, the formulation contained in this article is anyone who intentionally produces or circulate pharmaceutical preparations and/or medical devices that do not have a distribution permit as referred to in Article 106 paragraph (1), namely pharmaceutical preparations and medical devices can only be circulated after obtaining a distribution permit. Accountability in criminal law is carried out on the basis of error and some is carried out without having to prove the existence of the error (strict liability Errors can be divided into two types, namely intentional and negligence. Therefore, it is necessary to form a general health policy that can be implemented by all parties and at the same time can answer the challenges of the era of globalization and with the increasing complexity of health problems in a new Health Law to replace Law Number 23 of 1992 concerning Health with Law No. Law Number 36 Year 2009 concerning Health.

Keywords: Criminal; Aspects; Process, Illegal; Drugs.
\end{abstract}

\section{Introduction}

The Third Amendment to the 1945 Constitution of the Republic of Indonesia has added norms regarding the rule of law in Article 1 paragraph (3) of the Third Amendment to the 1945 Constitution of the Republic of Indonesia which reads: "The State of Indonesia is a state of law". ${ }^{1}$ This provision is a form of normalization that comes from the content in the Elucidation of the 1945 Constitution of the Republic of Indonesia which states "The Indonesian state is based on law (Rechtsstaat) not based on mere power (Machtsstaat)". With the inclusion in the norms of the 1945 Constitution of the Republic of Indonesia, the concept of the rule of law in the Elucidation of the 1945 Constitution of the Republic of Indonesia has binding legal force as the highest norm in the national legal system of the Indonesian state. ${ }^{2}$

\footnotetext{
${ }^{1}$ Ahmad Firmanto Prasedyomukti and Rakhmat Bowo Suharto, "The Role of Judicial Commission on Supervision of Judge's Crime in Indonesia" in Jurnal Daulat Hukum Volume 1 Issue 4 December 2018, url: http://jurnal.unissula.ac.id/index.php/RH/article/view/3931/2793

${ }^{2}$ Nur Dwi Edie W, and Gunarto. "Analysis of Judicial Policy in Deciding Criminal Acts Based Alternative Indictment (Case Study Decision Number 82 / Pid.B / 2019 / PN.Blora)” in Jurnal Daulat Hukum Volume 3 Issue 1, March 2020, url:
} http://jurnal.unissula.ac.id/index.php/RH/article/view/8429/4063 
Terminologically, the term "state of law" in the provisions of Article 1 paragraph (3) of the Third Amendment to the 1945 Constitution of the Republic of Indonesia does not refer specifically to one of the main concepts in the Western legal tradition, both Rechtsstaat and the Rule of Law. This means that the term "state of law" in the 1945 Constitution of the Republic of Indonesia is a relatively 'neutral' concept that opens up space for interpretation for new understandings in accordance with the paradigm and reality of the Republic of Indonesia. ${ }^{3}$

The higher the civilization of a nation, the more advanced the science that develops in that nation. If the progress of science is not balanced with the spirit of humanity, it will have a negative effect on access. The emergence of new criminal acts in the developing field of science. Which causes disturbance of peace, tranquility and often causes material and immaterial losses to the community. ${ }^{4}$

Health development is part of the general welfare that must be realized as the ideals of the Indonesian people in the Preamble to the 1945 Constitution of the Republic of Indonesia. ${ }^{5}$ To obtain this health, it is supported by the presence of both modern and traditional medicines such as herbal medicine as well as health services and medical care according to existing standards. According to the World Health Organization (WHO), drug abuse is the use of drugs that are not used for treatment or medication, but are used for enjoyment. ${ }^{6}$ Based on the Regulation of the Head of BPOM No. 28 of 2018, that certain classes of drugs that are abused are drugs that work on the central nervous system in addition to narcotics and psychotropic substances such as Tramadol, Trihexyphenidyl, Chlorpromazine, Amitriptyline and Haloperidol. ${ }^{7}$ The effects of drug abuse include physical effects, psychological effects and social effects. ${ }^{8}$

One of the crimes in health law that is rife at this time is a crime in the pharmaceutical sector. Pharmacy is a profession that is related to the art and science of providing natural and synthetic materials that are suitable and enjoyable for distribution and use in medicine as prevention of a disease. ${ }^{9}$

The term "drug abuse" is actually not quite right because the term has different meanings for each person. There are things that distinguish the meaning of the term drug abuse from "drug misuse". Drug abuse tends to be interpreted as the use of drugs for non-medical purposes, usually to alter consciousness. While

\footnotetext{
${ }^{3}$ Beno, Gunarto and Sri Kusriyah. "Implementation of Fully Required Elements in the Crime of Planning Murder (Case Study in Blora State Court)" in Jurnal Daulat Hukum Volume 3 Issue 1, March 2020, url: http://jurnal.unissula.ac.id/index.php/RH/article/view/8404/4058

${ }^{4}$ Andin Rusmini. "Tindak Pidana Pengedaran dan Penyalahgunaan Obat Farmasi Tanpa Izin Edar Menurut Undang-Undang Nomor 36 Tahun 2009 Tentang Kesehatan" STIH Sultan Adam dalam Al'Adl, Volume VIII Nomor 3, September-December 2016, p. 24

${ }^{5}$ H. Zaeni Ashadie, 2017, Aspek-Aspek Hukum Kesehatan, Depok, Raja Grafindo Persada, p. 1

${ }^{6}$ Nada Widayanti dkk. "Studi Retroperspektif Penyalahgunaan Obat Pada Pasien Ketergantungan Obat di Rumah Saki Jiwa Sambang Lihum". in Media Farmasi Vol.12, September 2015, p.249

${ }^{7}$ Silvi Wulandari \& Resmi Mustarichie. "Upaya Pengawasa BBPOM di Bandung Dalam Kejadian Potensi Penyalahgunaan Obat" in Farmaka Vol 15 Nomor 4, 31 December 2017, p. 2

${ }^{8}$ Togiaratua Nainggolan. "Hubungan Antara Kepercayaan Diri Dengan Kecemasan Sosial Pada Pengguna NAPZA: Penelitian di Balai Kasih Sayang Parmadi Siwi” in Sosiokonsepsia, Volume 16 Nomor 02, 2011, p. 162

${ }_{9}^{9}$ Barda Nawawi Arief, 2008, Bunga Rampai Kebijakan Hukum Pidana, Kencana, Jakarta, p. 42.
} 
the wrong use of drugs tends to mean wrong indications, wrong doses or use for too long. ${ }^{10}$

Although the distribution of drugs has been strictly regulated in Act No. 36 of 2009 concerning Health and there are criminal threats for violators, in fact the circulation of dangerous drugs is still happening. Examples of dangerous drugs, namely Double L Pills (TRIHEKIFENIDIL HCL) are drugs that are included in list G drugs, the letter $\mathrm{G}$ comes from the word Gevaarlijk which means dangerous. Group $G$ drugs include hard drugs that can only be purchased with a doctor's prescription. ${ }^{11}$ So double $\mathrm{L}$ pills (TRIHEXIFENIDIL HCL) are not included in Narcotics or Psychotropics but are hard drugs. Called hard drugs because if the user does not pay attention to the dosage, instructions for use, and warnings given, it can cause dangerous effects and can only be obtained at pharmacies. The packaging is marked with a red circle with the letter $\mathrm{K}$ in the middle. ${ }^{12}$ In Act No. 36 of 2009 concerning Health, it is regulated regarding criminal provisions regarding sanctions for distributors of pharmaceutical preparations that do not meet safety standards and distribution permits. Pharmaceutical preparations are drugs, medicinal ingredients, traditional medicines and cosmetics. In this case, the double $\mathrm{L}$ pill is one of the pharmaceutical dosage forms because it contains (TRIHEXIFENIDIL HCL).

The description above has attracted the author's attention to study, understand, and research in greater depth regarding criminal sanctions for dealers who do not have the ability in the field of medicine or do not have a distribution permit in connection with the implementation of Act No. 36 of 2009 concerning Health with aspects the crime. Based on the above background, it is necessary to conduct research with the aim of knowing and analyze the implications of the criminal aspect in the implementation of the Health Law on perpetrators of drug abuse.

\section{Research Methods}

The approach method used in this study is a normative juridical approach. The research specification is descriptive analytical. The type of data used in this research is secondary data which includes primary legal materials, secondary legal materials and tertiary legal materials. The data collection technique in this study used the literature study method. The collected data were analyzed using qualitative descriptive analysis.

\section{Results and Discussion}

Understanding Law according to Utrecht is a set of rules (orders and prohibitions) that regulate the order in a society and must be obeyed by that society. ${ }^{13}$ Law was created for society, so the law must be in accordance with

\footnotetext{
10 Bertram G. Katzung, 2002, Farmakologi Dasar dan Klinik, Salemba Medika, Jakarta, p. 327

11 http://www.kamusbesar.com/55360/obat- List-g, Accessed on May 30, 2021.

${ }^{12}$ Regulation of the Minister of Health of the Republic of Indonesia No. 949/Menkes/Per/VI/2000.

13 C.S.T. Kansil, 1986, Pengantar Ilmu Hukum dan Tata Hukum Indonesia, Balai Pustaka, Jakarta p. 38
} 
developments in society. The law has a binding and coercive nature, so that the community has an obligation to obey and comply with these regulations/laws.

In simple terms, crime is defined as suffering intentionally given by the state to a person or persons as a result of actions which according to the rules of criminal law are prohibited acts. Therefore, every criminal act must clearly state the prohibited act along with strict criminal sanctions if the act is violated. The form of suffering in the form of punishment or punishment imposed by the state is regulated and determined in detail, including how to impose the criminal sanction and how to implement it. ${ }^{14}$ Based on the Criminal Code (KUHP), the types of punishments that are threatened are varied, which are broadly divided into basic and additional penalties. The main punishment consists of the death penalty, imprisonment, confinement and fines. Additional penalties consist of confiscation of certain goods, revocation of certain rights and announcement of judge's decision.

Illegal drugs as a form of elaboration of drugs, which stands for narcotics and illegal drugs. ${ }^{15}$ While what is meant by medicine there are also several meanings, namely drugs are materials used to affect physiological systems (body functions and parts) or patrol conditions in the context of determining diagnosis, prevention (preventive), healing (curative), recovery (rehabilitative) and health improvement. ${ }^{16}$ According to the World Health Organization (WHO), drug abuse is the use of drugs that are not used for treatment or medication, but are used for enjoyment. ${ }^{17}$

Based on the Regulation of the Head of BPOM No. 28 of 2018, that certain classes of drugs that are abused are drugs that work on the central nervous system in addition to narcotics and psychotropic substances such as Tramadol, Trihexyphenidyl, Chlorpromazine, Amitriptyline and Haloperidol. ${ }^{18}$ The effects of drug abuse include physical effects, psychological effects and social effects.

The establishment of Act No. 36 of 2009 concerning Health which replaced the previous Law, namely Act No. 23 of 1992 concerning Health, is a form of government movement in seeking better health for the community than before. The background for the formation of Act No. 36 Of 2009 includes (a) Act No. 36 Of 2009 is more complete than the previous Law; (b) Act No. 36 Of 2009 concerning Health brings a new paradigm; and (c) Legal challenges in the health sector.

Act No. 36 of 2009 concerning Health which regulates drug abuse, among others:

1) Article 196

Any person who intentionally produces or distributes pharmaceutical preparations and/or medical devices that do not meet the

\footnotetext{
${ }^{14}$ Eddy O.S. Hiariej, 2014, Prinsip-Prinsip Hukum Pidana, Yogyakarta, Cahaya Atma Pustaka.

${ }^{15}$ Defry Dwi Irmawan and Anis Mashdurohatun. "Disparities Criminal Case Against Judge's Decision In Crime Of Narcotics Abuse Viewed From The Purpose Of Criminal Law" in Jurnal Daulat Hukum Volume 1 Issue 4 December 2018, url: http://jurnal.unissula.ac.id/index.php/RH/article/view/4141/2891

${ }^{16}$ Suprapto, 1999, Penyalahgunaan Obat-Obatan Terlarang dan Kaitannya dengan Peraturan Perundang-undangan yang Berlaku serta Pengaruhnya Karena Pengedar Secara Bebas Khusus Bagi Generasi Muda Remaja, Riau, Kantor Wilayah Departemen Kesehatan, p. 3

17 Nada Widayanti, et al, 2015, Op.Cit, p. 249.

${ }^{18}$ Silvi Wulandari \& Official Mustarichie, 2017, Op.Cit, page 2.
} 
standards and/or requirements for safety, efficacy or benefit, and quality as referred to in Article 98 paragraph (2) and paragraph (3) shall be subject to a maximum imprisonment of 10 (ten) years and a maximum fine of IDR 1,000,000,000 (one billion rupiah).

2) Article 197

Anyone who intentionally produces or distributes pharmaceutical preparations and/or medical devices does not have a distribution permit as referred to in Article 106 paragraph (1), shall be sentenced to a maximum imprisonment of 15 (fifteen) years and a maximum fine of IDR $1,500,000,000$ (one billion five hundred million rupiah).

In the application of Act No. 36 of 2009 concerning Health, criminal acts of abuse of drugs that are not narcotics and psychotropics can be subject to 2 (two) articles in Act No. 36 of 2009 concerning Health, namely Article 196 and Article 197.

In general, those who are allowed to trade and distribute drugs are pharmacies, especially hard drugs and mandatory pharmacy drugs (OWA). In pharmacies, hard drugs that are allowed to be sold only by factories to pharmaceutical wholesalers (PBF), PBF to pharmacies, and pharmacies to patients using a doctor's prescription, must also be accompanied by markings and information and the amount must not be in large quantities. Drug production that is allowed is a drug factory or pharmaceutical industry that already has CPOB (good way of making drugs) and has a production permit as a drug factory.Meanwhile, for the activities of storing and/or distributing drugs, pharmaceutical wholesalers and pharmacies provide health services. ${ }^{19}$

In distributing pharmaceutical drugs to consumers for general purposes, a person must have a distribution permit. What is meant by a distribution permit is a permit from the BPOM (Food and Drug Supervisory Agency) authorities, the Health Service, and the Licensing Service. In addition to distribution permits, the standards used in pharmaceutical preparations are pharmacopoeial standards, pharmacopoeial standards are standards of quality and quantity by weight.

In general, cases of drug abuse are subject to the Health Law, which in Articles 196 and 197, for anyone who distributes drugs without a distribution permit and/or produces drugs without expertise and/or does not meet the standards. This shows that there is flexibility for consumers, because they cannot be processed legally.

A person who has committed a health crime and has fulfilled the elements of a crime must be held criminally accountable. The person must be responsible by accepting the punishment that has been imposed on him due to the criminal act he has committed, namely distributing pharmaceutical preparations without a distribution permit. People who have committed a crime of distributing pharmaceutical preparations without this distribution permit must be directly responsible for their actions. The person must be responsible because in the criminal act he made there was an element of error in the form of intentional.

\footnotetext{
${ }^{19}$ Andin Rusmini. "Tindak Pidana Pengedaran dan Penyalahgunaan Obat Farmasi Tanpa Izin Edar Menurut Undang-Undang Nomor 36 Tahun 2009 tentang Kesehatan" in Al-adl, Volume VIII Nomor 3, September-December 2016, p. 36
} 
Criminal responsibility in foreign terms is called teorekenbaardheid or criminal responsibility which leads to the criminalization of the perpetrator with the intention of determining whether a defendant or suspect is responsible for a criminal act that occurred or not. ${ }^{20}$ The issue of criminal liability is closely related to the element of error. This can be seen in Article 6 paragraph (2) of Act No. 48 of 2009 concerning Judicial Power which states that: "No one can be sentenced to a crime, unless the court, because of the legal evidence according to the law, is convinced that someone who is deemed to be responsible, has been guilty of the act he is accused of." From the provisions of the article, it is clear that the element of error is an element that will determine the consequences of a person's actions, namely in the form of imposing a crime. To determine the existence of an error, a person must meet several elements, namely: 1) the ability to be responsible for the maker. $^{21}$

The elements of a criminal act in Article 196 of Act No. 36 Of 2009 are: 1) Objective elements: (-) Acts: producing or distributing; (-) The object is: pharmaceutical preparations and/or medical devices; Those that do not meet the standards and/or requirements for safety, efficacy or benefit, and quality as referred to in Article 98 paragraph (2) and paragraph (3). 2) Subjective element: intentionally.

There are two actions, namely producing or distributing. It could be the maker who performs the act of producing or distributing it. The object of the crime which is also the object of the two acts is pharmaceutical preparations and/or medical devices. Pharmaceutical preparations are drugs, medicinal ingredients, traditional medicines, and cosmetics (Article 1 Point 4). Medical devices are instruments, apparatus, machines and/or implants that do not contain drugs that are used to prevent, diagnose, cure and alleviate disease, treat sick people, restore health to humans, and/or form structures and improve body functions (Article 1 point 1 5). The unlawful nature of the two acts lies in the object, namely pharmaceutical preparations and/or medical devices that are produced or circulated that do not meet safety standards and/or requirements.

\section{Closing}

In the application of the Act on the crime of distributing and abusing pharmaceutical preparations without a distribution permit as regulated in Article 197 of Act No. 36 of 2009 concerning Health, the formulation contained in this article is anyone who intentionally produces or distributes pharmaceutical preparations and or / medical devices that do not have a distribution permit as referred to in Article 106 paragraph (1), namely pharmaceutical preparations and medical devices can only be circulated after obtaining a distribution permit. Accountability in criminal law is carried out on the basis of error and some is carried out without having to prove the existence of the error (strict liability). Errors can be divided into two types, namely intentional and negligence.

\footnotetext{
${ }^{20}$ Amir Ilyas, 2012, Asas-Asas Hukum Pidana (Memahami Tindak Pidana dan Pertanggungjawaban Pidana Sebagai Syarat Pemidanaan), Rangkang Education \& Pukap Indonesia, Yogyakarta, p.73

${ }^{21}$ Sudarto, 1983, Hukum dan Perkembangan Masyarakat, Sinar Baru, Bandung, p. 73
} 
Therefore, given that it is still difficult to distinguish drugs without a marketing authorization from drugs with a distribution permit, it is hoped that the government will provide education to the public and provide information about drugs that have been withdrawn from the market. Then in handling the crime of distributing and abusing pharmaceutical preparations without a permit, a regulation that specifically regulates the crime of distributing pharmaceutical preparations without a permit should be made, so that in dealing with this crime, the legal apparatus and related parties can take firm action because of the legal umbrella against this crime is clear along with all the explanations.

\section{References}

\section{Journal}

[1] Ahmad Firmanto Prasedyomukti and Rakhmat Bowo Suharto, "The Role of Judicial Commission on Supervision of Judge's Crime in Indonesia" in Jurnal Daulat Hukum Volume 1 Issue 4 December 2018, url: http://jurnal.unissula.ac.id/index.php/RH/article/view/3931/2793

[2] Andin Rusmini, "Tindak Pidana Pengedaran dan Penyalahgunaan Obat Farmasi Tanpa Izin Edar Menurut Undang-Undang Nomor 36 Tahun 2009 Tentang Kesehatan" in Al'Adl, Volume VIII Nomor 3, September-December 2016

[3] Beno, Gunarto and Sri Kusriyah, "Implementation of Fully Required Elements in the Crime of Planning Murder (Case Study in Blora State Court)" in Jurnal Daulat Hukum Volume 3 Issue 1, March 2020, url: http://jurnal.unissula.ac.id/index.php/RH/article/view/8404/4058

[4] Defry Dwi Irmawan and Anis Mashdurohatun, "Disparities Criminal Case Against Judge's Decision In Crime Of Narcotics Abuse Viewed From The Purpose Of Criminal Law" in Jurnal Daulat Hukum Volume 1 Issue 4 December 2018,

url:

http://jurnal.unissula.ac.id/index.php/RH/article/view/4141/2891

[5] Nada Widayanti dkk, "Studi Retroperspektif Penyalahgunaan Obat Pada Pasien Ketergantungan Obat di Rumah Saki Jiwa Sambang Lihum" in Media Farmasi Vol.12, September 2015

[6] Nur Dwi Edie W, and Gunarto, "Analysis of Judicial Policy in Deciding Criminal Acts Based Alternative Indictment (Case Study Decision Number 82 / Pid.B / 2019 / PN.Blora)" in Jurnal Daulat Hukum Volume 3 Issue 1, March 2020,

http://jurnal.unissula.ac.id/index.php/RH/article/view/8429/4063

url:

[7] Silvi Wulandari \& Resmi Mustarichie, "Upaya Pengawasa BBPOM di Bandung Dalam Kejadian Potensi Penyalahgunaan Obat" in Farmaka Vol 15 Nomor 4, 31 December 2017

[8] Togiaratua Nainggolan, "Hubungan Antara Kepercayaan Diri Dengan Kecemasan Sosial Pada Pengguna NAPZA: Penelitian di Balai Kasih Sayang Parmadi Siwi" in Sosiokonsepsia, Volume 16 Nomor 02, 2011 


\section{Books}

[1] Barda Nawawi Arief, 2008, Bunga Rampai Kebijakan Hukum Pidana, Kencana, Jakarta

[2] Bertram G. Katzung, 2002, Farmakologi Dasar dan Klinik, Salemba Medika, Jakarta

[3] C.S.T. Kansil, 1986, Pengantar Ilmu Hukum dan Tata Hukum Indonesia, Balai Pustaka, Jakarta

[4] Eddy O.S. Hiariej, 2014, Prinsip-Prinsip Hukum Pidana, Yogyakarta, Cahaya Atma Pustaka

[5] Soemitro, 1998, Metodologi Penelitian Hukum dan Jurimetri, Jakarta, Ghalia Indonesia

[6] Suprapto, 1999, Penyalahgunaan Obat-Obatan Terlarang dan Kaitannya dengan Peraturan Perundang-undangan yang Berlaku serta Pengaruhnya Karena Pengedar Secara Bebas Khusus Bagi Generasi Muda Remaja, Riau, Kantor Wilayah Departemen Kesehatan

[7] Zaeni Ashadie, 2017, Aspek-Aspek Hukum Kesehatan, Depok, Raja Grafindo Persada

\section{Internet}

[1] http://www.kamusbesar.com/55360/obat-daftar-g 